\title{
Propagation and seedling growth of some species used as ornamental hedges in landscape design
}

\author{
Tinuke Irene Odusanya ${ }^{1 *}$, Christiana Olusola Owolabi ${ }^{1}$, Olatunde Musibau Olosunde ${ }^{1}$, \\ Goke Jacob Bodunde ${ }^{1}$, Joy Nwakaego Odedina ${ }^{2}$
}

\begin{abstract}
Propagation and seedling growth characteristics of five plant species: Duranta repens (Yellow bush), Hamelia patens (Fire bush), Ficus retusa (Yellow ficus), Buxus sempervirens (Boxwood / West indies) and Acalypha wilkesiana (Copper leaf), were examined in the nursery as indices of suitability for use as hedge plants in the landscape. The experiment was laid out in a Completely Randomized Design (CRD) with four replicates where the treatments were the plant species. Cuttings were cultivated in polyethylene pots filled with top soil medium. Data collected included: time to rooting, rooting percentage, number of leaves/plant, seedling height and stem girth. They were subjected to analysis of variance and means separated using Least Significant Difference (LSD) at 5\% probability level. It took Acalypha wilkesiana, Duranta repens and Hamelia patens species shortest time (21 days) to root while Buxus sempervirens and Ficus retusa took the longest time (28 days) for rooting. Duranta repens species produced the highest rooting percentage $(80.5 \%)$ at 28 days after planting and the highest number of leaves/plant (15leaves). This study revealed Duranta repens as the easiest to propagate among these species. All plant species evaluated except Ficus retusa are easily propagated in the nursery thus indicating their potential suitability for commercial production in the nursery and use as hedge plants. Duranta repens and Buxus sempervirens are recommended as hedge plant choices based on their ease of propagation and early establishment.
\end{abstract}

Keywords: Stem cutting, nursery, hedge plants, rooting

\section{Introduction}

Succesful seedling establishment is largely dependent on the capacity of seedling to rapidly initiate roots (Grossnickle, 2005; Anthony and Douglass, 2005) Indeed, rooting through asexual methods of propagation is commonly used (Manica et al., 2000; Awan et al., 2012; Qadri et al, 2018). The rate of multiplication through cuttings is higher than for any other vegetative propagation techniques, with the exception of micro-propagation (Haider et al., 2015). There are different rooting behaviors among different plant species, and some plants root easily through cuttings while some are difficult to root (Qadri et $\mathrm{al}, 2018$ ). The art of propagation by cuttings is a very old and popular technique in the field of horticulture. However, there are many species which are difficult to root (Anu Rajan and Radhakrishna, 2013). The use of cuttings from stems, leaves, roots or terminal buds are considered the most commonly applied technique due to its practicability and simplicity especially in developing countries like Nigeria (Okunlola, 2013).
Ljung (2013) reported that auxins play very important role to enhance success of propagation when applied to hardwood cuttings and increase the root initiation in plants. Ornamental hedges are a very important part of environmental beautification and management; they make public parks and houses more conducive for relaxation and enjoyment (Day and Loveys, 1998, Okunlola, 2013).

Hedges are the initial element of landscape to form a landscaping. Due to their importance in landscaping they are in replaceable for their purposes. They provide aesthetically pleasing landscape features that can have positive benefits for psychological wellbeing. They also offer natural screens that hide unsightly developments and protect people's privacy. They are commonly used for such purposes as screening out an undesirable view, wind barrier, defining an activity area or property line, or to add an expanse of uniform mass and line to the landscape design (Mathews et al., 2014; Mistitis). Hedges also provide noise reduction especially in urban areas where noise is easily refracted from hard surfaces like pavements or buildings. Plants are better at absorbing high-frequency sounds,

\footnotetext{
${ }^{1}$ Federal University of Agriculture, Department of Horticulture, Abeokuta, Nigeria. *Corresponding author: tinuodus18@gmail.com

${ }^{2}$ Federal University of Agriculture, Department of Plant Physiology and Crop Production, Abeokuta, Nigeria.
} 
which are most bothersome to human ears, than they are at absorbing low frequency sounds (Fare and Clatterbuck, 1998).

According to Matthews et al. (2014), hedges are also important for humans and wildlife. They provide a wide range of services that help support the healthy functioning of ecosystems. They are a good source of food (flowers, berries, and nuts) for insects, birds and mammals. Hedges control ecosystem processes like air quality, water purification, and pollination. In terms of the air we breathe, hedges help produce oxygen and capture harmful particulates, especially important in urban areas that produce more atmospheric pollutants. They also help reduce the urban heat island effect and store carbon. Hedges are widely used to demarcate boundaries, as visual screenings, and as sound barriers, therefore they are important in the landscape from a functional point of view. Because the landscape use of hedges require dense and consistent plantings, hedges often require close planting and demand high volumes of plants for its success, depending on the species and landscape design goals. Besides its functional uses, hedges are also grown for the display of aesthetic features including flowers, leaves, scent and overall foliage texture- fruit, stem and bark. They are a valuable tool for the harmonious and practical resolution of many physical site problems, and they provide durable aesthetic satisfaction (Armstrong, 2000, Okunlola, 2013).

A hedge may consist of shrubs and/or shrublets or short trees, usually of similar species, planted closely together in a line. It is also the continuous line which the individuality of each plant is lost (Hessayon, 1992; Mitra, 2013). Brun and Dinius (2015), define hedges as closely spread linear strips of vegetation that perform a variety of valuable functions in an urban environment. According to Hildreth (1958), hedges are probably the most popular type of ornamental planting, and the sustained interest of planting is due to the increasing tendency to beautify home surroundings and increased need for the privacy afforded by hedge screens in private and public premises.

Report has suggested that hedges are generally the preferred landscaping treatment in public and private landscapes (Kendal et al. 2008). This shows how important their propagation success for commercial production and adequate utilization of hedges in landscaping projects and environmental beautification. Studies, however, are yet to provide guidance as to preference or relative suitability of plant species as hedges. Thus, this study was to establish the ease of propagation and evaluate seedling growth characteristics of some plant species as factors of suitability for use as hedges in a landscape.

\section{Materials and Methods}

The stem cuttings of Duranta repens, Hamelia patens, Ficus retusa, Buxus sempervirens and Acalypha wilkesiana were obtained from erect branch of healthy plants in a landscape of about ten years of establishment at the Federal University of Agriculture Abeokuta, Nigeria (Latitude $7^{0} 25^{\prime}$ $\mathrm{N}$, Longitude $3^{0} 25^{1} \mathrm{E}$ ), located in a rainforest ecology. Semi hardwood stem cuttings of about $10-15 \mathrm{~cm}$ long made from these five plant species based on presence of nodes. Sharp secateurs were used for cutting the stem.

They were rooted in polyethylene pots of size $19 \times 12.5$ $\mathrm{cm}$, filled with forest top soil. The whole experiment was conducted under normal nursery conditions of Department Horticulture, Federal University of Agriculture Abeokuta, Nigeria. Treatment was arranged in a Completely Randomized Design (CRD) with four replicates. The experimental site had an annual rainfall of $1146.30 \mathrm{~mm}$ but $390.3 \mathrm{~mm}$ for the period of the study from September to November while the mean daily maximum and minimum temperatures were $32.86^{\circ} \mathrm{C}$ and $23.22^{\circ} \mathrm{C}$, respectively (Table 1 ). 
Table 1. Meteorological data during the period of the experiment (2016)

\begin{tabular}{|c|c|c|c|c|}
\hline \multirow[t]{2}{*}{ Parameter } & \multirow[t]{2}{*}{ Rainfall(mm) } & \multicolumn{2}{|c|}{ Temperature $\left({ }^{\circ} \mathrm{C}\right)$} & \multirow[t]{2}{*}{ Sunshine (hr) } \\
\hline & & Maximum & Minimum & \\
\hline \multicolumn{5}{|l|}{ Months } \\
\hline January & 32.00 & 35.40 & 20.70 & 4.00 \\
\hline February & 0.00 & 36.40 & 24.20 & 3.30 \\
\hline March & 150.30 & 34.80 & 24.40 & 2.00 \\
\hline April & 68.20 & 34.20 & 24.40 & 6.30 \\
\hline May & 226.20 & 33.50 & 24.30 & 5.10 \\
\hline June & 150.50 & 30.60 & 22.70 & 4.00 \\
\hline July & 65.20 & 29.70 & 23.00 & 2.80 \\
\hline August & 63.60 & 28.90 & 22.70 & 1.95 \\
\hline September & 229.00 & 30.50 & 23.60 & 2.70 \\
\hline October & 155.40 & 32.30 & 22.60 & 4.90 \\
\hline November & 5.90 & 32.70 & 23.50 & 5.50 \\
\hline December & 0.00 & 35.30 & 22.50 & 5.50 \\
\hline Total (rainfall) & 1146.30 & & & \\
\hline Mean (temperature) & & 32.86 & 23.22 & 4.00 \\
\hline
\end{tabular}

Source: Meteorological Station, Department of Water Resources Management and Agro Meteorology, Federal University of Agriculture, Abeokuta. na: not available

Cuttings were assessed for rooting formation / rooting initiation beginning from 7days after planting, rooting percentage (using Anu and Radhakrishna (2013) formula: Number of cuttings with roots/ Number of cuttings planted) x 100). Number of leaves per plant, seedling height from the soil level to the shoot apex of the plant using a meter rule and the stem girth measured using a Vernier caliper at $5 \mathrm{~cm}$ seedling height above soil level. Data collection started at four weeks after planting (WAP) and continued until 9WAP Data collected were subjected to analysis of variance procedure using $\mathrm{R}$ statistical package and means were separated using Least Significant Difference, at 5\% probability level.

\section{Results and Discussion}

There was significant difference $(p \leq 0.05)$ in the number of days to rooting for the species propagated. Acalypha wilkesiana, Duranta repens and Hamelia patens had the shortest time to root (21 days) while Buxus sempervirens and Ficus retusa rooted in 28 days (Table 2). 
Table 2. Number of days to root and rooting percentage of the species propagated in the nursery

\begin{tabular}{|c|c|c|}
\hline Plant species & Days to Rooting & Rooting Percentage(\%) \\
\hline Acalypha wilkesiana & 21 & 73.5 \\
\hline Buxus sempervirens sempervirens & 28 & 69.0 \\
\hline Duranta repens repens & 21 & 80.5 \\
\hline Ficus retusa retusa & 28 & 42.9 \\
\hline Hamelia patens patens & 21 & 66.4 \\
\hline LSD(0.05) & 1.08 & 10.1 \\
\hline
\end{tabular}

Observation of difference in time to rooting of stem cutting of Acalypha wilkesiana, Duranta repens, Hamelia patens, and Buxus sempervirens agreed with the report of Qadri et al. (2018) that there rooting behavior could vary among different plant species. Some plants start rooting easily while some hardly rooted through cuttings even when treated with hormones. In addition, reports from Jaenicke (1999) stated that as soon as a good quality seedling is established, roots begin growing rapidly. Rooting percentage at 28 days after planting in the nursery differed significantly $(\mathrm{p} \leq 0.05)$ among the species propagated (Table 2). Duranta repens having, the highest rooting percentage $(80.5 \%)$ followed by Acalypha wilkesiana (73.5\%), Buxus sempervirens (69\%) and Hamelia patens $(66.4 \%)$. According to Jaenicke (1999), root development is important for good inoculation with symbionts, for efficient nutrient uptake and for out planting success. The number of fine roots with growing points largely determines the ability of the seedling to recover and start growing after planting out in the landscape. Also Julia et al. (2013); Hartmann et al. (2002); Smalley and Dirr (1987) reported that twonode cuttings may root better than single-node cuttings because they have greater reserves of carbohydrates and endogenous root morphogens and auxin. Ficus retusa had the least rooting percentage (42.9\%) (Table 2) supporting the report by Ibrahim (2007) that the percentages of rooting of Ficus retusa cuttings tended to be very low.

The species propagated were significantly different $(\mathrm{p} \leq$ 0.05 ) with respect to the number of leaves per plant across sampling times. Duranta repens producing significantly highest number (105) of leaves, followed closely by Buxus sempervirens (82) and Hamelia patens (18). Acalypha wilkesiana (13) and Ficus retusa (8) produced the least number of leaves (Figure1).

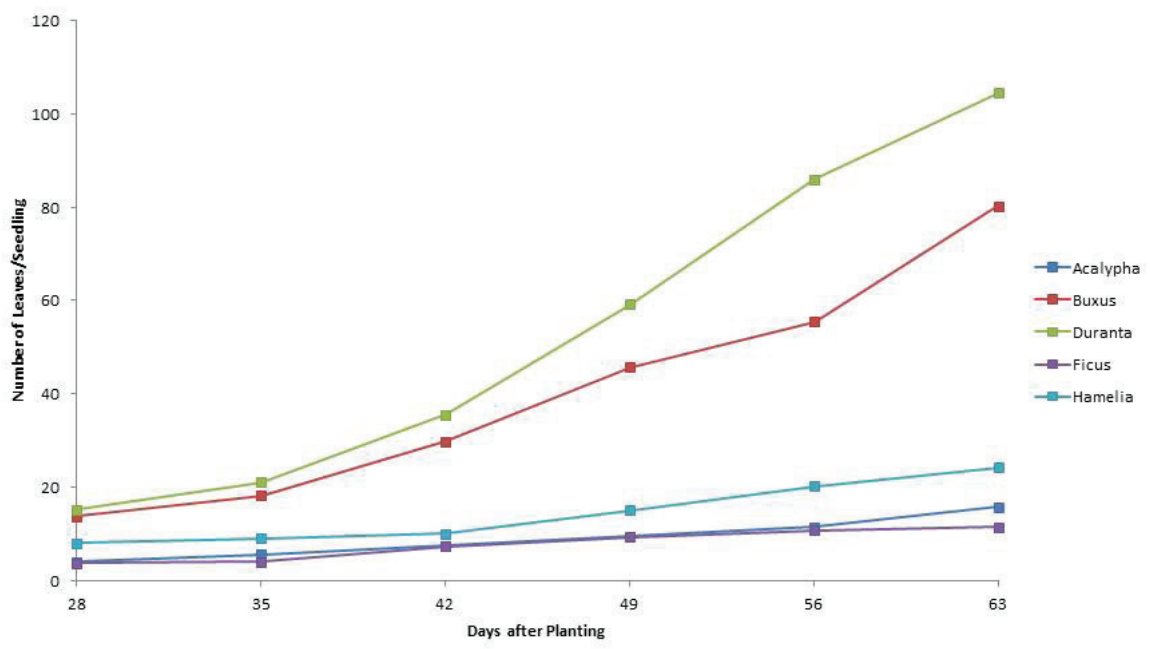

Figure 1. Number of leaves per seedling of the five species in the nursery 
This observation of highest number of leaves in Duranta repens is probably attributed to early rooting which aids nutrient and water absorption into highly growing with more leave production. This aligned with report of Janick (1986) that an important component of the capacity for a stem to root is the nutritional status of the plant. The vigorous rooting enabled the cuttings to absorb more nutrients and produce more leaves, (Reuveni and Raviv, 1981; Karaguzel, 1997; Okunola 2013).

Hamelia patens was significantly $(\mathrm{p} \leq 0.05)$ taller than the other species from 35 to 63 days after planting
However, statistically species were similar in their height in the order of Buxus sempervirens > Acalypha wilkesiana $>$ Ficus retusa $>$ Duranta repens. There were however no significant difference $(\mathrm{p} \leq 0.05)$ in seedling height of Buxus sempervirens and Acalypha wilkesiana at 42 to 49days after planting (Figure 2). According to Bayley and Kietzka (1997);

Jacob et al 2005; Anthony and Douglass (2005), a good quality seedling is one that is of appreciable height and possesses the largest stem girth with adequate leaves number.

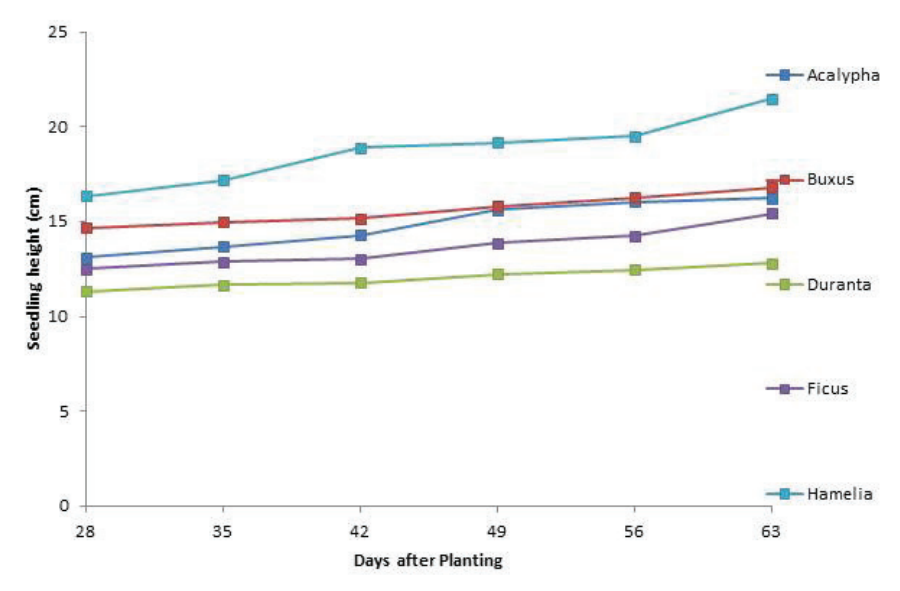

Figure 2. Seedling height $(\mathrm{cm})$ of species propagated in the Nursery

There were significant differences in the stem girth of species propagated across sampling period with the widest girth observed from the seedlings of Acalypha wilkesiana followed by Ficus retusa, Hamelia, Buxus sempervirens and Duranta repens, respectively (Figure 3). Widest girth observed from seedlings of Acalypha wilkesiana could be linked to it earliness to initiation and development of root to support growth of shoot.

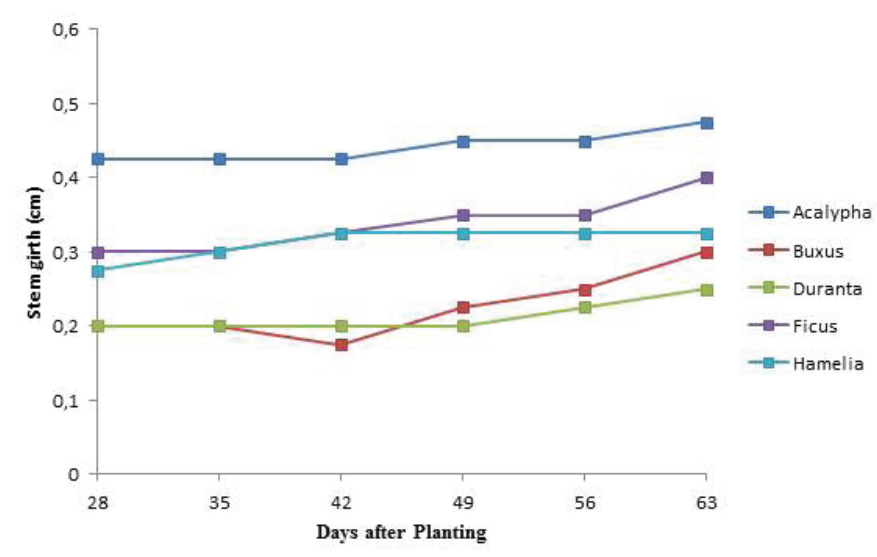

Figure 3. Stem girth $(\mathrm{cm})$ of seedlings of species propagated in the nursery 


\section{Conclusion}

The plant species considered in this study except no Ficus retusa can be easily propagated in the nursery as seen in their early root formation and relatively high rooting percentage and seedling vigor, thus indicating potential suitability for use as a hedge plant. Duranta repens and Buxus sempervirens are recommended as hedge plant choices for landscaping based on their ease of propagation and establishment in the nursery.

\section{Author Contribution}

T.I.O. ${ }^{0000-0001-5336-7664}$ : carried out the research as part of the fulfillment of the requirements for the Degree of Master of Agriculture. G.J.B.: was the major supervisor for research. O.M.O. ${ }^{0000-0001-9463-9451}$, J.N.O.: Co-supervisor for the research. C.O.O. ${ }^{0000-0002-8415-321 x}$ : analyzed the data collected for the research and edit the manuscript.

\section{References}

ANTHONY S.D.; DOUGLASS F. J. Quantifying root system quality of nursery seedlings and relationship to out planting performance. New Forests, v.30. p.295-311. 2005. DOI 10.1007/s11056-005-7480-y.

ANU RAJAN, S.; RADHAKRISHNA, D. Effect of entophytic bacteria on the rooting and establishment of cuttings of hibiscus (Rosa sinensis). Journal of Agriculture and Veterinary Science, v.3, n.2, p.17-21, 2013

ARMSTRONG, D. A survey of community gardens in upstate New York: Implications for health promotion and community development. Health and Place, v.6, p.319327,2000 .

AWAN, A.A.; ULLAH, E.; ABBAS, S.J.; KHAN, O.; MASROOR, S. Growth response of various olive cultivars to different cutting lengths. Pakistan Journal of Agriculture Science, v.49,p.283-287, 2012

BAYLEY A.D.; KIETZKA J.W. Stock quality and field performance of Pinus patula seedlings produced under two nursery growing regimes during seven different nursery production periods. New Forest, v.13, p.341-356, 1997.

BRUN, C.; DINIUS, P. Selecting plants for screen and hedges EM089E. Pullman: Washington: Washington State University Extension, p.1-18, 2015.

CARTABIANO, J.A.; LUBE, J.D. Propagation of four underused native species from softwood cuttings. Hortscience, v.48, n.8, p.1018-1020, 2013.
DAY, J.S.; LOVEYS, B.R. Propagation from cuttings of two woody ornamental Australian shrubs Boronia megastigma and Hypocalymna angustifolium Endl. (white myrtle). Australian Journal of Experimental Agriculture, v.38, p.201-206, 1998.

DAVID, K.; WILLIAMS, K.; ARMSTRONG, L. Preference for and performance of some australian native plants grown as hedges. Urban Forestry and Urban Greening, v.7, p.93-106, 2008.

FARE, D.; CLATTERBUCK, W. Evergreen trees for screens and hedges in the landscape: trees for Tennessee landscapes sp 517. Tennessee: Agricultural Extension Service, University of Tennessee, p.1-4, 1998.

FINNERTY, T. Landscaping. In: Idaho Master Gardner Program Handbook. Idaho: University of Idaho Extension, p.1-8, 1994.

GROSSNICKLE S.C. The importance of root growth in overcoming planting stress. New Forest in press. 2005.

HARTMANN, H.T.; KESTER, D.E.; DAVIES JR., F.T.; GENEVE, R.L. Plant propagation: Principles and practices, 7ed. Pearson Education Ltd.:Upper Saddle River, NJ. 2002.

HESSAYON, D.G. Tree and shrub expert. Herts(England): Transworld publishers, 2008. pp.128.

HILDRETH, A.C. Ornamental hedges for the central great plains. Washington DC: Farmers' bulletin No. 2019, U.S. Department of Agriculture, 1958.

IBRAHIM, N.Y. Propagation of Ficus retusa nitida L. by cuttings technique. Sudan: Department of Horticuture, Faculty of Agriculture, University of Khartoum-Khartoum, p.1-71, 2007.

JACOBS D.F., SALIFU K.F. AND SEIFERT J.R. Relative contribution of initial root and shoot morphology in predicting field performance of hardwood seedlings. New Forests in press. 2005

JAENICKE, H. Good tree nursery practices: practical guidelines for research nurseries. World Agroforestry Centre. 1999.

LJUNG, K. Auxin metabolism and homeostasis during plant development. Development, v.140, p.943-950, 2013. MATHEWS F.; MACDONALD D.; MORGAN D.; OWEN R.; PALMER R.; STALEY J.; THOMSON H. Hedgerows and hedgerow trees. The Woodland Trust: 2014. p.1-16. 
MANICA, I. Propagation. In: MANICA, I.; ICUMA, I.M.; JUNQUEIRA, N.T.V.; SALVADOR, J.O.; MOREIRA, A.; MALAVOLTA, E. (eds.). Tropical Fruit-6: Guava. Porto Alegre: Five Continents, 2000. p.85-111,

MISITIS, M. Ornamental plants commonly used as hedges in South Florida. Florida: IFAS Extension, University of Florida: p.1-11.

MITRA, S. A handbook on landscape. India: s.n.

OKUNLOLA, I. The effects of cutting types and length on rooting of Duranta repens in the nursery. Global Journal of Human Social Science Geography, Geo-Sciences, Environmental \& Disaster Management, v.13, n.3, p.1-4, 2013.

QADRI, R.; AZAM, M.; KHAN, S.B.; KHAN, I.; UL HAQ, I.; YANG, Y.; MUZAMMIL J., M.; GHANI, M. A.; MOAZZAM, M. Growth performance of guava cutting under different growing media and plant cutting taking height. Bulgarian Journal of Agricultural Science, v.24, n.2, p.236-243, 2018
SMALLEY, T.J.; DIRR, M.A. Effect of cutting size on rooting and subsequent growth of Acer rubrum 'Red Sunset' cuttings. Journal of Environmental Horticulture, v.5, p.122-124, 1987,

STOECKLEIN, M.C. The Complete Plant Selection Guide for Landscape Design. West Lafayette, Indiana: Purdue University Press. 2001.

WHITE, J.; CURTIS, W.S. Landscape Design and Horticulture, Adapted from the Texas Master Gardener Manual. (The Diagnostic Process). p.1-40, 2010. 